\title{
Desain Komik Strip Matematika pada Materi Statistika untuk Kelas VI Tingkat Sekolah Dasar
}

\author{
Syarifah Nadiyah $^{1}$, Finna Yunilia Wijaya ${ }^{2}$, \& Arif Rahman Hakim ${ }^{3}$ \\ ${ }^{1}$ Aqila Bimbel, Jatinegara, Jakarta Timur. ${ }^{2,3}$ Program Studi Pendidikan Matematika, Universitas Indraprasta PGRI Jakarta.
}

\section{INFO ARTICLES}

\section{Article History:}

Received: 02-Juni-2019

Revised: 15-Juni-2019

Approved: 26-Juni-2019

Publish Online: 28-Juni-2019

\section{Key Words:}

Media Pembelajaran, Komik Strip Matematika.

\section{c) (i) (2)}

This article is licen under a Creative Commons AttributionShareAlike 4.0 International License.

\begin{abstract}
This study aims to develop instructional materials that are less attractive, become mathematics teaching materials in the form of comic strip designs. The development research carried out in the even semester of the 2018/2019 academic year took place in two schools, namely: Cipinang Cempedak 04 Elementary School East Jakarta and SD Assalafy Cipinang Cempedak, East Jakarta. Using research and development methods, research and development with ADDIE learning model. Based on the results of interviews with students and students conducted in two schools, learning mathematics using comic strip designs more aroused students' interest in learning. This comic strip teaching material is expected to facilitate teachers and parents to accompany students, and can have a significant influence.
\end{abstract}

\begin{abstract}
Abstrak: Penelitian ini bertujuan untuk mengembangkan bahan ajar berbentuk desain komik strip matematika. Penelitian pengembangan yang dilaksanakan pada semester genap tahun pelajaran 2018/2019 ini bertempat di dua sekolah, yaitu: SD Negeri Cipinang Cempedak 04 Pagi, Jakarta Timur dan SD Assalafy Cipinang Cempedak, Jakarta Timur. Penelitian ini menggunakan metode research and development dengan model ADDIE yang terbatas pada tahap Analisys, Design, dan Depelovement. Berdasarkan hasil wawancara dengan guru dan siswa yang dilakukan di dua sekolah tersebut, belajar matematika menggunakan komik strip matematika lebih membangkitkan minat siswa dalam belajar. Komik strip matematika ini dapat memfasilitasi guru dan orangtua untuk kegiatan belajar siswa, baik di sekolah ataupun di rumah.
\end{abstract}

Correspondence Address: Jln. Kebon Nanas Selatan 2 RT.5 RW.5 No.7C, Kelurahan Cipinang Cempedak, Kecamatan Jatinegara, Jakarta Timur, 13340, Indonesia; e-mail: syaripahnadiah@gmail.com

How to Cite (APA $6^{\text {th }}$ Style): Nadiyah, S., Wijaya, F. Y., \& Hakim, A. R. (2019). Desain Komik Strip Matematika pada Materi Statistika untuk Kelas VI Tingkat Sekolah Dasar. JKPM (Jurnal Kajian Pendidikan Matematika), 4(2): $135-146$.

Copyright: Nadiyah, S., Wijaya, F. Y., \& Hakim, A. R. (2019)

Competing Interests Disclosures: The authors declare that they have no significant competing financial, professional or personal interests that might have influenced the performance or presentation of the work described in this manuscript. 


\section{PENDAHULUAN}

Secara umum, matematika merupakan salah satu mata pelajaran yang paling penting dalam kehidupan, karena segala sesuatu membutuhkan perhitungan matematis. Berbagai hal di sekitar kita yang berhubungan dengan matematika diantaranya tentang aljabar, pengukuran, dan geometri. Hal ini sesuai dengan pendapat James (Suherman, dkk., 2001: 18), bahwa 'matematika adalah ilmu tentang logika mengenai bentuk, susunan, besaran, dan konsep-konsep yang berhubungan satu dengan yang lainnya dengan jumlah yang banyak yang terbagi ke dalam tiga bidang, yaitu aljabar, analisis, dan geometri'. Matematika merupakan mata pelajaran yang wajib diajarkan pada jenjang pendidikan dasar, menengah sampai dengan perguruan tinggi. Apabila dilihat dari konten yang diujikan untuk dimensi kognitif dalam TIMSS yang terdiri dari tiga domain, siswa Indonesia dalam pembelajaran matematika memperoleh skor rata-rata 378 untuk domain pengetahuan, 384 untuk penerapan dan 388 untuk penalaran. Sementara itu, jika dilihat dari konten matematika yang diujikan, siswa Indonesia memperoleh skor rata-rata untuk bilangan 375, aljabar 392, geometri 377, data dan peluang 376 (Annajmi, 2018: 2). Berdasarkan hasil yang diperoleh tersebut menunjukkan masih rendahnya siswa dalam menyelesaikan soal matematika. Rendahnya hasil matematika, salah satu penyebab utamanya ialah pembelajaran yang kurang tepat.

Menurut Arifin (2010:10), "Pembelajaran merupakan suatu proses atau kegiatan yang sistematis dan sistemik yang bersifat interaktif dan komunikatif antara pendidik dengan siswa, sumber belajar, dan lingkungan untuk menciptakan suatu kondisi yang memungkinkan terjadinya tindakan belajar siswa. Proses pembelajaran pada awalnya mengharuskan guru untuk mengetahui kemampuan dasar yang dimiliki oleh siswa meliputi kemampuan dasarnya, motivasinya, latar belakang akademisnya, latar belakang ekonominya, dan lain sebagainya. Kesiapan guru untuk mengenal karakteristik siswa dalam pembelajaran merupakan modal utama yang sangat penting dalam penyampaian bahan belajar dan menjadi indikator suksesnya proses pembelajaran. Hakim (2017) menyatakan bahwa, "Memberikan pemahaman kepada peserta didik tidak bisa dipaksakan dengan begitu saja. Memberikan pemahaman kepada peserta didik untuk konsep matematika harus disesuaikan dengan perkembangan pola pikir peserta didiknya."

Tidak dapat dipungkiri bahwa dalam setiap rangkaian kegiatan pembelajaran matematika, motivasi belajar siswa masih tergolong rendah. Hal tersebut bisa dilihat dari keinginan siswa dalam belajar masih kurang, kegiatan belajar kurang menarik karena siswa cenderung pasif dan jarang mengajukan pertanyaan. Untuk peningkatan keinginan dan motivasi siswa dalam proses pembelajaran matematika, diperlukan bahan ajar yang terlihat lebih menarik bagi siswa. Pembelajaran matematika seyogyanya dapat adaptif mengikuti trend pembelajaran matematika. Hakim (2017) menjelaskan bahwa, segenap trend pembelajaran lain yang ada hendaknya bisa diikuti serta dilaksanakan dengan sebaik-baiknya oleh guru atau orangtua dalam kegiatan pembelajaran matematika. Dengan demikian, sangatlah penting kiranya untuk para guru mau membuka diri untuk menyesuaikan segala hal terkait dengan trend pembelajaran matematika. Salah satu alternatif trend pembelajaran matematika yang dapat dilaksanakan adalah menggunakan media belajar berupa komik strip matematika sesuai dengan materi yang dibahas secara formal di dalam kelas.

Media berasal dari bahasa latin medius yang secara harfiah berarti tengah, perantara, atau pengantar (Arsyad, 2013: 3). Media belajar sebagai pengantar bagi siswa untuk belajar di ruang kelas diharapkan dapat meningkatkan kualitas proses pembelajaran. Menurut Sudjana \& Rivai (2010: 2), media pengajaran dapat mempertinggi proses belajar siswa dalam pengajaran yang pada gilirannya diharapkan dapat mempertinggi hasil belajar yang dicapainya. Beberapa manfaat lain yang dapat diperoleh dengan menggunakan media pembelajaran, diantaranya pengajaran akan lebih menarik perhatian siswa sehingga dapat menumbuhkan motivasi belajar. Namun pada kenyataannya, seringkali dijumpai komunikasi verbal guru yang monoton, sehingga secara umum siswa bosan dan belajar tidak komunikatif. 
Menurut Arjuna (2011:3), komik strip (strip comics) merupakan sebuah gambar atau rangkaian gambar yang berisi cerita. Biasanya komik strip terdiri dari tiga sampai enam panel atau sekitarnya. Penyajian dari isi cerita dapat juga berupa humor atau banyolan atau cerita yang serius dan juga menarik untuk disimak di setiap periodenya hingga ceritanya tamat. Komik merupakan suatu kartun yang mengungkapkan sebuah karakter dan memerankan cerita dalam urutan yang erat, dihubungkan dengan gambar dan dirancang untuk memberikan hiburan kepada para pembaca. Peranan pokok komik dalam instruksional adalah kemampuannya dalam menciptakan minat peserta didik (Rohani, 2014:77-79). Secara lebih tegas, Pritandhari (2016) menyatakan bahwa media pembelajaran komik strip berisi gambar atau rangkaian gambar yang membentuk sebuah cerita yang dibuat berdasarkan materi yang dipelajari. Media dibuat dengan cerita dan tampilan yang menarik agar menarik siswa untuk membaca. Ketika siswa membaca komik tersebut secara tidak langsung tanpa mereka sadari mereka sedang belajar matematika.

Siswa dalam usia tingkat Sekolah Dasar, lebih menyukai bahan ajar yang terdapat banyak gambar di dalamnya. Berdasarkan penelitian pendahuluan berupa wawancara terhadap beberapa siswa kelas VI tingkat Sekolah Dasar, peneliti mendapatkan informasi bahwa semua siswa memiliki jawaban yang hampir sama dalam pemilihan metode pembelajaran. Kemudian, sumber belajar yang digunakan di sekolah mereka adalah buku paket dan lembar kerja siswa. Siswa cenderung kurang tertarik belajar menggunakan lembar kerja siswa. Mereka setuju jika media pembelajaran dirubah menggunakan media pembelajaran komik strip. Berdasarkan latar belakang di atas, peneliti berkeinginan untuk meneliti sesuatu yang baru. Seperti membuat bahan ajar menggunakan komik strip guna mengetahui lebih jauh pengembangan bahan ajar komik strip pada materi statistika. Untuk itu peneliti mengambil judul: "Desain Komik Strip Matematika pada Materi Statistika untuk Kelas VI Tingkat Sekolah Dasar”.

\section{METODE}

Penelitian ini bertujuan untuk mengembangkan bahan ajar berbentuk desain komik strip matematika. Penelitian pengembangan yang dilaksanakan pada semester genap tahun pelajaran 2018/2019 ini bertempat di dua sekolah, yaitu: (1) SD Negeri Cipinang Cempedak 04 Pagi, yang terletak di Jalan Pedati Kebon Nanas Utara Cipinang Cempedak, Jatinegara, Jakarta Timur, Kode Pos 13340; dan (2) SD Assalafy, yang terletak di Jalan Kebon Nanas Utara II/3, Cipinang Cempedak, Jatinegara, Jakarta Timur, Kode Pos 13340. Metode penelitian yang digunakan adalah metode research and development. Model penelitian yang dipilih adalah model pengembangan ADDIE (Branch, 2011), yaitu pengembangan yang terdiri dari lima tahapan yang meliputi analisis (analysis), desain (design), pengembangan (development), implementasi (implementation), dan evaluasi (evaluation). Secara teknis dalam penelitian ini hanya dibatasi pada tahapan $A D D$, yaitu analisis (analysis), desain (design), pengembangan (development).

1. Analisis (Analysis), tahap awal yakni melakukan wawancara untuk menganalisis kebutuhan belajar siswa yang dilihat dari gaya belajar siswa serta menganalisis kompetensi yang akan dimuat dalam bahan ajar berbentuk desain komik strip matematika pada materi statistika.

2. Desain (design), dilakukan pemilihan format media, pemilihan materi, contoh soal dan jawaban dalam bahan ajar berbentuk desain komik strip matematika pada materi statistika serta perancangan desain media secara keseluruhan berupa story board yang dilengkapi dengan story line.

3. Pengembangan (development), berupa pengembangan yang dilakukan pembuatan bahan ajar berbentuk desain komik strip matematika pada materi statistika menggunakan personal computer dan laptop. Seluruh komponen yang telah dipersiapkan pada tahap desain, diproduksi menjadi bahan ajar berbentuk 
desain komik strip matematika pada materi statistika. Setelah bahan ajar berbentuk desain komik strip matematika pada materi statistika selesai dibuat, kemudian menguji keabsyahan atau kevalidan oleh validator ahli media, validator ahli materi, dan respons dari responden yang dalam hal ini perwakilan siswa kelas VI di SD Negeri Cipinang Cempedak 04 Pagi dan SD Assalafy.

\section{HASIL}

Pengembangan bahan ajar berbentuk desain komik strip matematika ini sesuai dengan langkahlangkah prosedur penelitian research and development model ADDIE yang dibatasi pada tahap ADD, yaitu: Analysis (Analisis), Design (Desain), dan Development (Pengembangan). Berikut penjelasan tahaptahap dalam pengembangan bahan ajar berbentuk desain komik strip matematika yang dapat digunakan dalam pembelajaran matematika sesuai dengan tahapan $A D D$.

1. Penelitian Pendahuluan

Sebelum pengembangan media belajar pada materi statistika untuk tingkat Sekolah Dasar ini dilakukan, peneliti melakukan penelitian pendahuluan melalui studi kepustakaan, wawancara, dan observasi pada siswa dan guru matematika di SD Negeri Cipinang Cempedak 04 Pagi dan SD Assalafy. Berdasarkan hasil wawancara dengan guru matematika di SD Negeri Cipinang Cempedak 04 Pagi dan SD Assalafy, semua guru memiliki jawaban yang hampir sama dalam pemilihan metode pembelajaran. Guru di SD Negeri Cipinang Cempedak 04 Pagi dan SD Assalafy masih sama, yaitu menggunakan metode ceramah, diskusi, latihan, dan penugasan. Secara umum, mereka mengatakan pembelajaran menggunakan media membutuhkan waktu yang cukup lama. Oleh sebab itu, guru di SD Negeri Cipinang Cempedak 04 Pagi dan SD Assalafy lebih sering memilih metode ceramah yang difasilitasi dengan menggunakan buku, papan tulis, dan penugasan melalui lembar kerja siswa.

Penelitian pendahuluan di dua sekolah tersebut memiliki alasan yang sama untuk penggunaan media belajar dalam proses pembelajaran matematika, yaitu perlu meluangkan waktu lebih, baik dalam persiapan ataupun proses pembelajarannya, sehingga waktu efektif belajarnya hanya tersisa sedikit. Maka dari itu, materi yang menggunakan alat peraga hanya bangun datar saja, alat peraganya pun dibuat oleh siswa sebagai tugas mereka di rumah. Dan pembahasan lainnya seperti pertambahan, pengurangan, perkalian, pecahan, ataupun statistika disampaikan dengan cara ceramah, tanya jawab, dan latihan agar anak terbiasa dengan soal tersebut.

2. Analisis Kebutuhan (Tahap Analysis)

Berdasarkan pada hasil studi pendahuluan berupa hasil wawancara dengan siswa di SD Negeri Cipinang Cempedak 04 Pagi dan SD Assalafy, siswa mudah bosan dengan metode belajar yang sudah ada selama ini. Seperti yang telah diuraikan oleh peneliti dalam studi pendahuluan, bahwa di dua sekolah tersebut, guru lebih memilih metode pengajaran dan alat peraga yang dirasa mudah untuk diaplikasikan, tanpa memerlukan persiapan yang rumit dan tidak membutuhkan waktu yang lama.

Hasil analisis kebutuhan juga diperoleh informasi bahwa masih banyak siswa yang merasa bosan dengan metode pembelajaran yang selama ini digunakan oleh guru. Siswa ingin ada sesuatu yang lebih bervariasi agar mereka semangat dalam belajar matematika tanpa merasa bosan. Oleh karena itu, dibutuhkan media untuk membantu proses pembelajaran, agar siswa tidak merasa jenuh ataupun mengantuk pada saat guru menjelaskan di depan kelas. Dengan demikian, terdapat hal yang menjadi kebutuhan yang sangat perlu untuk ditingkatkan, yaitu mengenai media pembelajaran matematika yang digunakan guru dalam mengajar khususnya pada materi statistika. Adapun hasil wawancara dengan siswa di SD Negeri Cipinang Cempedak 04 Pagi dan SD Assalafy, bahwa dalam pembelajaran 
matematika, khususnya pada materi statistika sebagian besar siswa mengalami kesulitan dengan apa yang dimaksud dan juga merasa bosan dengan pembelajaran yang monoton. Guru di SD Negeri Cipinang Cempedak 04 Pagi dan SD Assalafy juga merasakan adanya hambatan pada materi statistika, kadang siswa terbalik dengan pemahaman apa itu mean, modus, atau median. Sehingga guru terus mengingatkan siswa ketika memberi tugas, terus mengingatkan apa itu mean, median, dan modus.

Mengikuti perkembangan saat ini, anak lebih menyukai membaca buku komik daripada buku pelajaran mereka sendiri, karena buku pelajaran tidak banyak memuat gambar gambar menarik. Jawaban tersebut saya dapatkan ketika saya menganalisis beberapa siswa. Dan rata-rata jawaban mereka, lebih menyukai buku cerita bergambar. Berdasarkan kebutuhan tersebut, peneliti membuat media belajar untuk membantu guru dan siswa serta orangtua dari siswa dalam pembelajaran matematika khususnya pada materi statistika. Pengembangan media belajar komik strip dapat dijadikan sebagai salah satu alternatif solusi yang dapat menampung kebutuhan orangtua, guru, dan siswa. Siswa seperti sedang membaca cerita namun ternyata secara tidak langsung mereka sedang belajar tentang materi statistika, baik secara konseptualnya maupun secara operasionalnya.

Media belajar kemudian dapat diimplementasikan di sekolah dalam proses pembelajaran dan juga dapat digunakan di rumah sebagai alat belajar latihan pada siswa dalam mempelajari materi statistika. Setelah menetapkan materi yang akan dibuat medianya, selanjutnya peneliti menganalisis karakteristik materi berdasarkan tujuan materi matematika statistika yang akan dibuatkan medianya. Karena materi Statistika terdapat di kelas VI, dengan demikian materi statistika diambil dari materi kelas VI tingkat sekolah dasar dengan standar kompetensi, kompetensi dasar, dan indikator yang sesuai dengan media yang akan dibuat. Dengan kalimat lain, pengembangkan bahan ajar berbentuk desain komik strip matematika merujuk pada standar kompetensi, kompetensi dasar, dan indikator yang sesuai dengan kebutuhan di SD Negeri Cipinang Cempedak 04 Pagi dan SD Assalafy.

3. Desain Media (Tahap Design)

Komik strip matematika yang berisi materi statistika, khususnya tentang "Pengolahan Data" ini dirancang dengan tujuan membuat media belajar yang mendidik, dapat diterima, kualitas baik, tampilan menarik dan membuat siswa lebih semangat belajar, dan menyenangkan dipelajari dimanapun. Komik strip matematika ini memiliki konsep untuk memudahkan kegiatan belajar, khususnya mata pelajaran matematika dengan memanfaatkan kemajuan teknologi berupa smartphone yang membuat media belajar menjadi sebuah aplikasi yang dapat diakses dimanapun, dan komik strip ini juga dapat diprint dan dijilid seperti buku komik pada umumnya. Jika tidak ingin diprint, maka dapat dilihat menggunakan smartphone. Belajar jadi lebih fleksibel dan menyenangkan. Materi pembelajarannya dibuat berdasarkan kebutuhan guru dalam mengajar materi statistika dan materi pada komik ini diambil dari berbagai sumber, yaitu beberapa buku paket matematika kelas VI tingkat Sekolah Dasar.

Pada tahapan desain, peneliti merancang sebuah story board, yang isinya: tokoh, latar, ilustrasi, dan story line. Tokoh yang ditetapkan oleh peneliti dalam mengembangkan bahan ajar berbentuk desain komik strip matematika adalah tiga tokoh utama dan dua tokoh pendukung. Adapun tokoh utamanya ada tiga, yaitu: Mea, Medi, dan Modu. Kemudian tokoh pendukungnya ada dua, yaitu: tukang buah dan tukang ikan. Bagian lain berupa latar dari desain komik strip matematika ada di pasar dengan seting cerita Mea, Medi, dan Modu belanja buah dan belanja ikan. Cerita yang disusun terdiri dari dua buah cerita dengan jumlah delapan segmen. Komunikasi yang dibangun dalam cerita komik strip matematika tentang belanja buah dan belanja ikan dengan merujuk pada materi pengenalan data di materi statistika kelas VI tingkat Sekolah Dasar. Secara keseluruhan, hasil dari perancangan desain media berupa story board pada penelitian ini ditampilkan dalam gambar 1. 


\begin{tabular}{|c|c|c|c|c|}
\hline Tokoh & Latar & Ilustrasi & Segmen & Story Line \\
\hline $\begin{array}{l}\text { Mea, } \\
\text { Medi, } \\
\text { Modu. }\end{array}$ & Pasar & & 1 & $\begin{array}{l}\text { Modu } \\
\text { ke pasar? } \\
\text { Mea } \\
\text { Medi } \\
\text { yang banyak ya ka }\end{array}$ \\
\hline
\end{tabular}

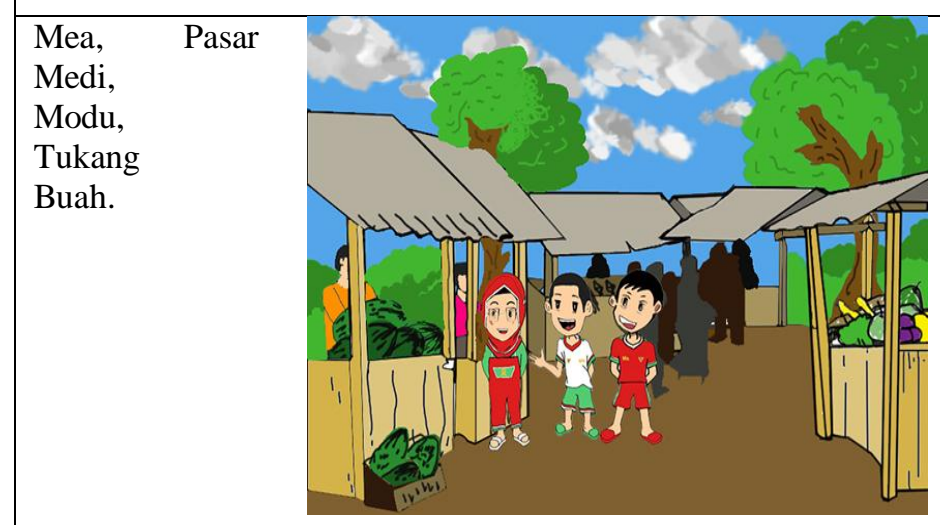

2

Mea : Pak, harga

semangkanya berapa?

Tukang buah $\quad$ : Rp5000/kg

Mea : Semangkanya berapa

kg beratnya pak?

Tukang buah : Macam-macam de, ini $2 \mathrm{~kg}, 3 \mathrm{~kg}, 2 \mathrm{~kg}, 4 \mathrm{~kg}, 2 \mathrm{~kg}, 5 \mathrm{~kg}, 3 \mathrm{~kg}, 4 \mathrm{~kg}$, $2 \mathrm{~kg}$

Modu : Coba kamu tebak medi berapa modus berat semangka tersebut?

Medi : Modus itu apa ya?

Mea,
Medi,
Modu.




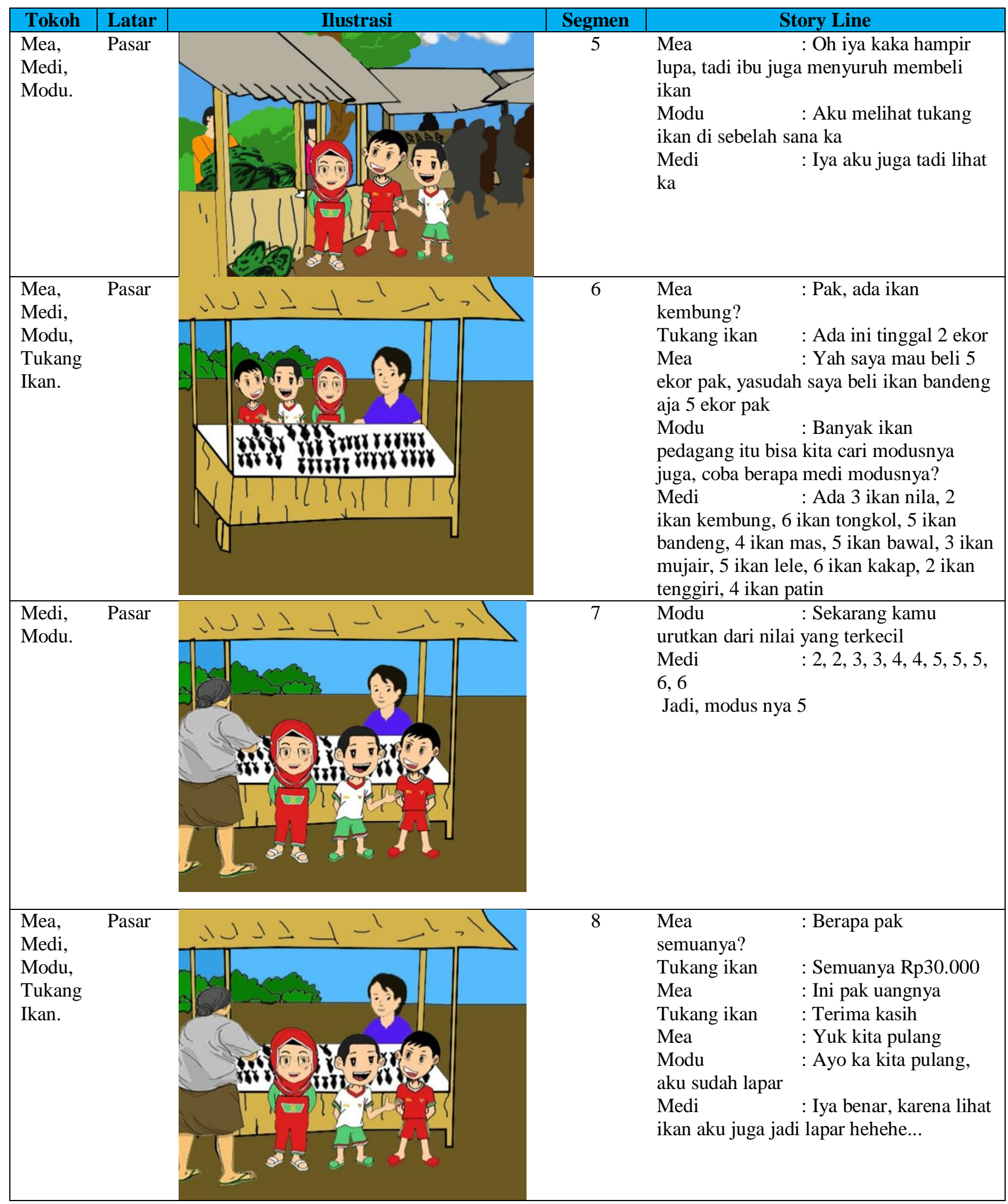

Gambar 1. Story Board Desain Bahan Ajar Berbentuk Desain Komik Strip Matematika. 


\section{Pengembangan Media (Tahap Development)}

Kegaitan yang dilakukan pada tahap ini adalah memproduksi media pembelajaran matematika kelas VI tingkat Sekolah Dasar untuk materi statistika berdasarkan desain story board. Proses pembuatan media pembelajaran ini menggunakan perangkat keras (hardware) yaitu Notebook ASUS TP203N, perangkat lunak (software) Windows 10, Adobe Photoshop CS6 dan Microsoft Paint 3D. Perangkat pembelajaran yang digunakan yaitu silabus SD dan buku paket SD kelas VI. Setelah perangkat pengembangan sudah siap, peneliti mulai memproses gambar latar manual terlebih dahulu menggunakan Microsoft Paint, Adobe Photoshop CS6 dan pencarian gambar di mesin pencari google sebagai referensi untuk memudahkan menggambar background manual. Setelah background dan perangkat pendukung selesai, selanjutnya peneliti memasukkan tokoh dan cerita atau dialog yang sudah disusun pada background. Kemudian, setelah selesai disusun, komik strip matematika lalu divalidasi. Secara keseluruhan, hasil pengembangan media komik strip matematika sebelum uji ahli media dan sebelum uji ahli materi ditampilkan pada gambar 2. Adapun setelah dilakukan uji ahli media dan setelah uji ahli materi dilakukan sedikit perbaikan, hasilnya ditampilkan pada gambar 3.

Setelah tahap development media selesai dilaksanakan, penelitian dilanjutkan dengan melakukan penilaian dari ahli atas komik strip matematika, yaitu dari ahli media dan ahli materi. Pada tahap ini yang dilakukan adalah penilaian oleh ahli materi dan ahli media yang ahli di bidangnya untuk menganalisis kelebihan dan kekurangan yang jika ditemukan beberapa kekurangan, maka segera dilakukan revisi oleh peneliti. Menurut para validator kualitas produk yang diuji mendapat nilai ratarata dari setiap ahli, yaitu ahli materi $87,27 \%$ dan ahli media $80,00 \%$. Dari rata-rata yang didapat, bahan ajar komik strip matematika dikategorikan baik dan telah memenuhi kualifikasi valid. Media pembelajaran ini dinilai layak untuk dijadikan alternatif media pembelajaran matematika di kelas VI tingkat Sekolah Dasar khususnya pada materi statistika.

Setelah dilakukan uji ahli yang dalam hal ini uji ahli media dan uji ahli materi, peneliti memperbaiki sedikit dari bagian desain komik strip matematika, yaitu pada bagian segmen tiga dan segmen tujuh. Awalnya ada percakapan data harus diurutkan, namun masukan dari ahli materi, data tidak harus diurutkan. Dengan demikian, peneliti merespons dengan memperbaiki sedikit bagian tersebut. Setelah diperbaiki, desain komik strip matematika dicobakan ke beberapa siswa sebagai responden dalam penelitian ini. Hasilnya adalah, siswa sangat antusias membaca komik ini dan siswa merasa senang dan mengerti atas materi statistika yang ditampilkan dalam bentuk komik strip.
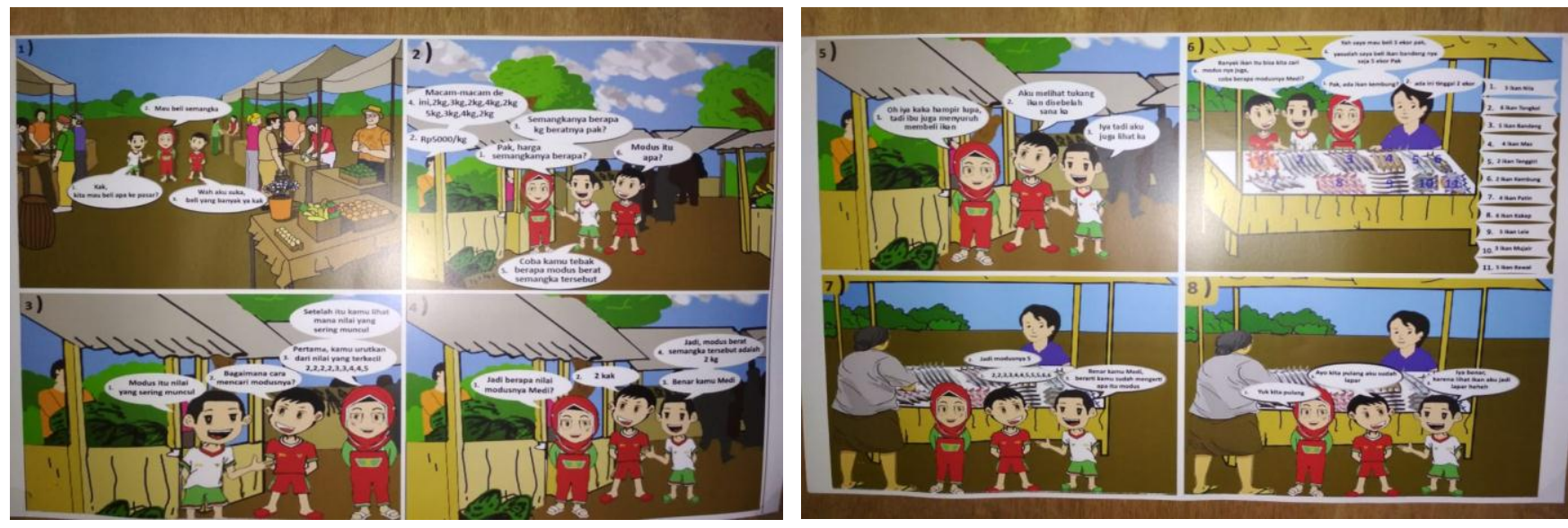

Gambar 2. Hasil Pengembangan Desain Bahan Ajar Berbentuk Desain Komik Strip Matematika Sebelum Dilakukan Uji Ahli Media dan Uji Ahli Materi. 

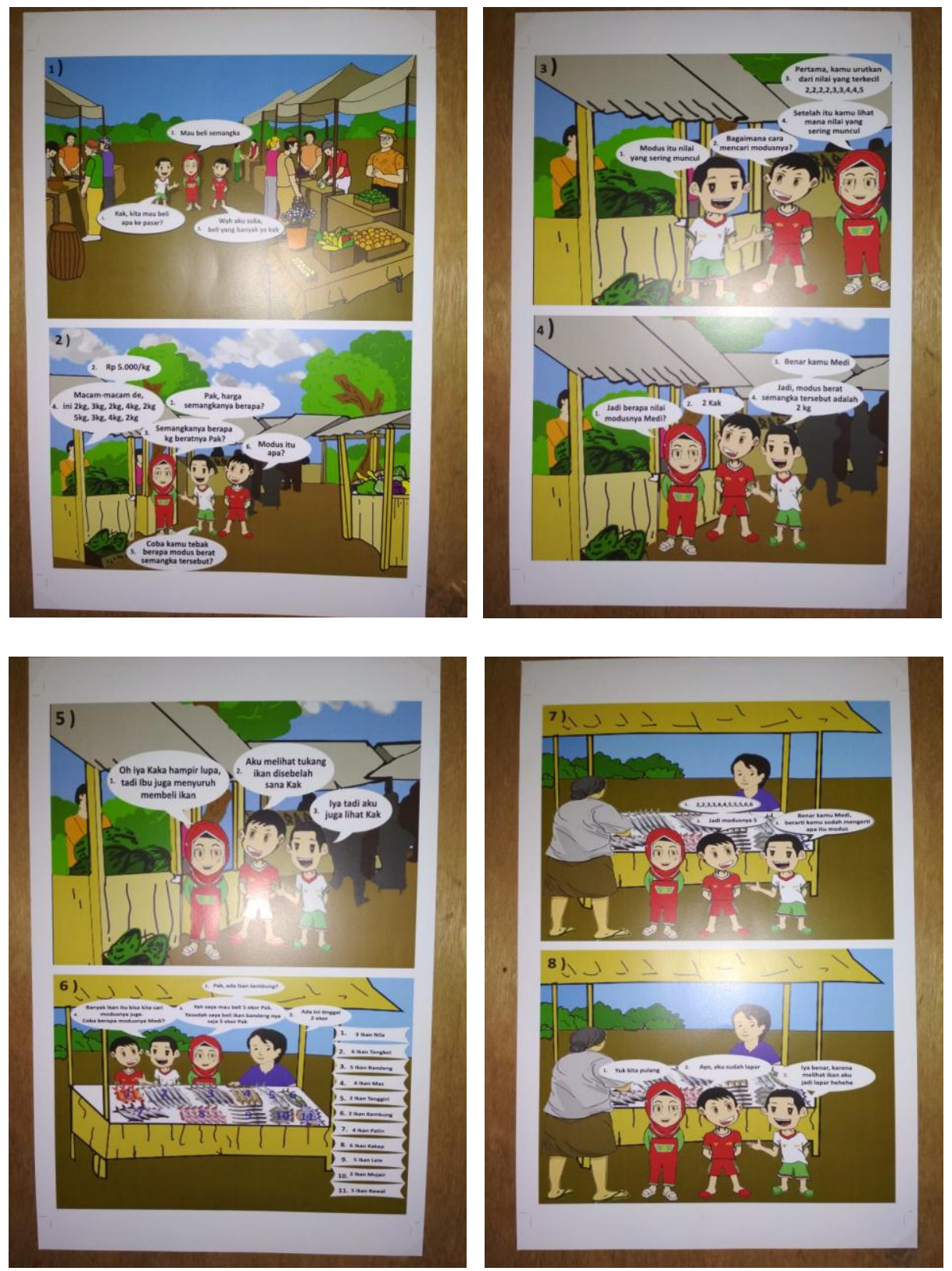

Gambar 3. Hasil Perbaikan dari Pengembangan Desain Bahan Ajar Berbentuk Desain Komik Strip Matematika Sesudah Dilakukan Uji Ahli Media dan Uji Ahli Materi.

\section{PEMBAHASAN}

Media pembelajaran yang dikembangkan yaitu media yang menjadi bahan ajar dalam pembelajaran matematika menggunakan komik strip. Media pembelajaran yang dikembangkan dapat dijalankan dimanapun dan kapanpun, karena dapat dishare melalui aplikasi whatsapp, messenger, twitter, instagram, bahkan bluetooth atau share it supaya tidak dikenakan biaya tambahan untuk mengirimnya. Komariah, 
dkk. (2018) menyatakan bahwa, "Media pembelajaran ini termasuk dalam kategori media pembelajaran berbasis mobile learning". Pengembangan bahan ajar yang dipaparkan di atas, yaitu bahan ajar komik strip matematika. Salah satu konsep dan inovasi terbaru tersebut adalah dengan memasukkan pembelajaran matematika ke dalam sebuah cerita bergambar seperti komik. Komik dapat dijadikan bahan ajar karena dapat mengefektifkan proses belajar mengajar, meningkatkan minat belajar siswa, dan menimbulkan minat apresiasi siswa. Komik merupakan salah satu media grafis yang digunakan dalam dunia pendidikan, berfungsi sebagai alat memperjelas materi, menciptakan nilai rasa lebih dalam memahami materi, menarik minat dan perhatian siswa, siswa merasa senang, membangkitkan rasa ingin tahu siswa, memotivasi siswa untuk belajar, dan lain-lain. Hal ini sejalan dengan Pritandhari (2016) yang menyatakan bahwa "Pemanfaatan media komik strip sebagai media pembelajaran dapat meningkatkan minat siswa dalam kegiatan pembelajaran”. Dengan kata lain, komik strip matematika secara teknis dapat lebih menarik minat dan perhatian siswa untuk giat belajar dan siswa menemukan situasi baru dalam kegiatan belajarnya.

Media komik strip matematika yang berhasil dikembangkan spesifik tentang materi statistik tingkat sekolah dasar. Tujuan pembelajaran statistik adalah membentuk dan mengembangkan kemampuan penalaran statistik (Sari, 2017). Dari hasil ujicoba yang telah dilakukan ke beberapa siswa sebagai responden dalam kelompok kecil, dapat disimpulkan bahwa media pembelajaran melalui komik strip dinilai baik digunakan dalam pembelajaran matematika. Komik strip matematika tentang statistika juga sangat memudahkan siswa untuk memahami pelajaran yang disampaikan, yaitu materi statistika. Dengan kata lain, siswa dengan membaca cerita komik strik matematika ini sudah berhasil mengembangkan penalaran statistiknya. Selain itu, materi pembelajaran tersebut juga dapat dipelajari lagi di rumah sambil santai, tanpa harus terbebani dengan membuka buku paket. Menurut Malasari, dkk. (2018), "Kelebihan media ini menyajikan materi yang dikemas secara singkat dan menarik dengan menampilkan slide pembelajaran interaktif yang berwarna, sehingga membuat siswa lebih antusias, sekaligus lebih bersemangat dalam mengikuti pembelajaran dan memudahkan siswa untuk cepat dalam memahami isi materi tersebut". Hal inilah yang menjadi dasar atas pernyataan siswa jadi lebih antusias untuk belajar.

Hidayat (Khasanah, 2018: 3), menyatakan bahwa "komik memiliki keunggulan, diantaranya adalah keunggulan visual serta tokoh-tokohnya yang cenderung menghibur, dan komik merupakan dunia yang dekat dengan anak-anak". Dalam komik strip matematika yang dikembangkan dalam penelitian ini dianggap sudah berhasil mengenalkan tokoh baru dalam diri siswa yaitu: Mea, Medi, dan Modu. Secara komunikatif, peneliti dan siswa sebagai responden terjalin stimulus-respons yang baik. Hal ini terjadi pada saat peneliti menjelaskan bahwasanya tokoh Mea itu diambil dari kata dasar mean yang berarti rata-rata, kemudian tokoh Medi itu diambil dari kata median yang berarti nilai tengah, serta tokoh Modu diambil dari kata modus yang berarti data yang sering muncul. Secara umum, keunggulan bahan ajar komik dalam bidang pendidikan antara lain memudahkan siswa dalam memahami buku pelajaran yang tertuang dalam komik tersebut. Karena lebih banyak siswa yang suka membaca jika ada gambarnya dan warnanya. Lalu, komik strip matematika ini lebih menekankan pengajaran melalui tokoh-tokoh yang ada di dalamnya, jadi siswa lebih merasa seperti membaca cerita saja, namun tanpa disadari mereka sedang belajar dengan suasana hati yang terhibur dalam suasana yang relatif baru dialami.

Diantara kelebihan sudah dipaparkan di atas, komik strip matematika dalam penelitian ini juga masih terdapat keterbatasan, komik ini hanya memuat materi saja tanpa adanya latihan soal. Informasi yang diambil juga hanya dari aspek kelompok kecil, tidak wawancara responden dalam kelompok besar. Setelah uji ahli media yang dilakukan, peneliti paham akan kekurangan dari media gambar seperti ukuran teks yang kurang konsisten dan resolusi gambar yang masih pecah. Namun, sebelum diaplikasikan ke sekolah, peneliti sudah melakukan revisi ulang sesuai dengan masukan yang peneliti terima dari ahli materi, dari ahli media, dan juga dari responden. 
Secara keseluruhan, komik strip matematika yang dikembangkan sudah menjawab masalah dan menunjukkan potensi yang ada dan sedikit besarnya memberikan alternatif solusi serta menyumbang perubahan yang lebih baik bagi pendidikan. Diantara banyak hal alternatif solusi yang dapat dilakukan guru dalam upaya peningkatan kualitas proses pembelajaran sekaligus sebagai upaya peningkatan hasil belajar siswa, khususnya dalam pembelajaran matematika, guru harus dapat terus berkreasi menampilkan hal-hal yang dianggap baru bagi diri siswa di ruang kelas. Dalam kalimat yang sangat sederhana, guru dalam pembelajaran matematika harus kreatif dan terus menerus berinovasi menghadirkan media pembelajaran matematika. Fahmi (2016) menyatakan bahwa, "kreativitas dalam pembelajaran matematika perlu terus dikembangkan, karena itu matematika mesti diajarkan secara menarik dan terhubung dengan dunia nyata sehingga peserta didik senang". Untuk konteks ini, pengembangan desain komik strip matematika pada materi statistika untuk kelas VI tingkat Sekolah Dasar merupakan bentuk kreativitas dari guru yang harus segera ditampilkan secara efektif dan efisien dalam pembelajaran matematika khususnya pada materi statistika. Pada bagian ini juga, komik strip matematika sudah berhasil dibangun dengankaidah menghubungkan materi dengan hal-hal nyata yang dialami siswa secara umum.

Melalui hasi penelitian ini, dengan tersedianya komik strip matematika pada materi statistika ini, guru dalam melaksanakan pembelajaran matematika tingkat sekolah dasar sudah tidak lagi monoton berupa ceramah atau komunikasi satu arah dari guru ke siswa. Komik strip matematika pada materi statistika ini sebagai fasilitas bagi guru bahkan orangtua dari siswa untuk rangkaian kegiatan belajar, baik di sekolah maupun di rumah. Konseptual materi statistik tingkat sekolah dasar sudah ditampilkan dalam bentuk cerita dalam komik. Substansi kajian berupa konsep dan simbol dalam belajar matematika dapat disampaikan guru dan orangtua dengan komik strip matematika ini. Sejalan dengan Sundayana (2016:29) yang menyatakan bahwa, "dengan menggunakan media, konsep dan simbol matematika yang tadinya bersifat abstrak menjadi konkret". Dengan demikian, pengenalan konsep statistika yang umumnya hanya disampaikan melalui ceramah satu arah, dengan komik strip matematika ini sudah tidak lagi terjadi. Karena siswa sudah dapat informasi tambahan berupa interaksi dengan komik.

\section{SIMPULAN}

Peneliti mengembangkan media belajar untuk kelas VI tingkat sekolah dasar, secara spesifik materi pembelajaran statistika. Tujuan penelitian untuk memberikan gambaran tentang belajar matematika yang menyenangkan menggunakan tokoh tokoh yang ada di dalam komik, baik tokoh utama maupun tokoh pendukung. Dengan bahan ajar komik strip matematika dapat digunakan untuk pembelajaran yang interaktif, sehingga menghilangkan rasa bosan pada siswa. Berdasarkan penelitian pengembangan yang interaktif pada materi pelajaran "Statistika" kelas VI sekolah dasar dibuat meggunakan Adobe Photoshop dan Microsoft Paint 2010. Penelitian yang dilakukan menggunakan langkah-langkah prosedur penelitian Research and Developmen model ADDIE yang terbatas pada tahap Analysis (Analisis), Design (Desain), dan Development (Pengembangan), yang dimodifikasi oleh peneliti. Penelitian ini menghasilkan produk bahan ajar komik strip matematika yang dapat dibaca menggunakan handphone, atau dipasang di mading sekolah, supaya memudahkan anak untuk membaca. Kualitas produk mendapatkan kriteria "baik" atau layak digunakan secara formal dalam kegiatan pembelajaran matematika. Komik strip matematika ini dapat memfasilitasi guru dan orangtua untuk kegiatan belajar siswa baik di sekolah ataupun di rumah. 


\section{DAFTAR RUJUKAN}

Annajmi. (2018). Kontribusi Disposisi Matematis terhadap Prestasi Belajar Matematika Siswa Kelas VIII SMPN 3 Tambusai. Eddumatica. 8: 2-8.

Arifin. (2010). Penelitian Pendidikan Metode dan Paradigma Baru. Bandung: Remaja Rosdakarya.

Arjuna. (2011). Komik sebagai Media Pembelajaran. Artikel. Diakses dari http://arjunabelajar.blogspot.com/2011/03/komik-sebagai-mediapembelajaran.html

Arsyad, A. (2013). Media Pembelajaran. Jakarta: Rajawali Pers.

Branch, R. M. (2011). Instructional Design: The ADDIE Approach. London: Springer.

Fahmi, F. K. (2016). Pengembangan Media Games Education dalam Pembelajaran Matematika. JKPM (Jurnal Kajian Pendidikan Matematika). 1(2): 216-226.

Hakim, A. R. (2017). Pembelajaran Matematika yang Mudah dan Menyenangkan Bagi Peserta Didik. Prosiding Diskusi Panel Nasional Pendidikan Matematika Fakultas Teknik, Matematika, dan Ilmu Pengetahuan Alam Universitas Indraprasta PGRI, 271-281.

Khasanah, A. F. (2018). Pengembangan Soal Cerita Menggunakan Komik Matematika Bernuansa Islami pada Materi Perbandingan Kelas VII. (Skripsi). Universitas Islam Negeri Sunan Ampel, Surabaya.

Komariah, S., Suhendri, H., \& Hakim, A. R. (2018). Pengembangan Media Pembelajaran Matematika Siswa SMP Berbasis Android. JKPM (Jurnal Kajian Pendidikan Matematika), 4(1): 43-52.

Malasari, N. \& Hakim, A. R. (2017). Pengembangan Media Belajar pada Operasi Hitung untuk Tingkat Sekolah Dasar. JKPM (Jurnal Kajian Pendidikan Matematika), 3(1): 15-22.

Pritandhari, M. (2016). Penerapan Komik Strip sebagai Media Pembelajaran Mata Kuliah Manajemen Keuangan Mahasiswa Universitas Muhammadiyah Metro. Jurnal Promosi: Jurnal Pendidikan Ekonomi UM Metro, 4(2): 1-7.

Rohani, A. (2014). Media Intruksional Edukatif. Jakarta: Rineka Cipta.

Sari, S. K. (2017). Pengembangan Desain Pembelajaran Statistika Berbasis IT Menggunakan Pendekatan Realistic Mathematics Education untuk Kelas VIII SMP. JNPM (Jurnal Nasional Pendidikan Matematika), 1(2): 290-304.

Sudjana, N. \& Rivai. (2010). Media Pengajaran. Bandung: Sinar Baru Algensindo.

Suherman, E., Turmudi, Suryadi, D., Herman, T., dkk. (2001). Common Text Book Strategi Pembelajaran Matematika Kontemporer. Bandung: JICA UPI.

Sundayana, R. (2016). Media dan Alat Peraga dalam Pembelajaran Matematika. Bandung: Alfabeta. 